\title{
KINERJA TOUR LEADER DALAM MENINGKATKAN PERILAKU PASCA PEMBELIAN DI MASA YANG AKAN DATANG \\ PAKET WISATA DI MARGA TOUR
}

(Survei terhadap Wisatawan yang Menggunakan Paket Wisata Marga Tour Bandung)

\author{
Anita Rahayu Triani \\ Ridwan Purnama \\ Heri Puspito Diyah Setiyorini \\ Manajemen Pemasaran Pariwisata FPIPS UPI
}

\begin{abstract}
ABSTRAK
Menanggapi perkembangan pariwisata Kota Bandung, usaha jasa pariwisata kian mengalami kemajuan seperti biro perjalanan wisata yang menawarkan jasa untuk pengaturan perjalanan wisata. Salah satu perusahaan dalam bidang biro perjalanan wisata yang sedang berkembang ialah Marga Tour. Dalam menunjang keberlangsungan kegiatan perjalanan wisata, setiap perusahaan biro perjalanan wisata membutuhkan peran seorang pemimpin tour atau tour leader. Tour leader merupakan seseorang yang berada dijajaran paling depan yang mewakili perusahaan dalam memimpin perjalanan dan memenuhi kebutuhan wisatawan selama kegiatan tour. Keahlian dan kecakapan seorang tour leader saat berinteraksi dengan para wisatawan atau konsumen yang menggunakan jasa tour disebut sebagai tour leader performance. Tour leader performance berasal dari Service Performance (SERVPERF). Dari hasil pra penelitian pada perilaku konsumen pasca pembelian (post purchase behavior) menunjukkan kecenderungan masih mudahnya konsumen berkeinginan untuk berganti produk (swicth). Oleh karena itu, penelitian ini bertujuan untuk memperoleh gambaran dan pengaruh mengenai tour leader performance $(X)$ dan post purchase behavior $(Y)$. Adapun populasi dalam penelitian ini adalah konsumen yang telah melakukan pembelian/menggunakan jasa perjalanan wisata di Marga Tour. Jenis penelitian yang digunakan adalah deskriptif verifikatif, dan metode yang digunakan adalah survei dengan teknik systematic random sampling, maka diperoleh jumlah sampel sebesar 100 responden. Teknik analisis data adalah path analyisis (analsis jalur).
\end{abstract}

Kata Kunci: Tour Leader Performance, Post Purchase Behavior

\section{PENDAHULUAN}

\subsection{Latar Belakang Penelitian}

Kota Bandung merupakan salah satu destinasi wisata unggulan di Indonesia. Pariwisata Kota Bandung memiliki ragam wisata yang cukup lengkap antara lain wisata seni \& budaya, wisata alam, wisata buatan, wisata religi, wisata heritage dan juga wisata minat khusus yang kita banyak diminati wisatawan antara lain wisata belanja dan wisata kuliner.

Wisatawan nusantara (wisnus) di Kota Bandung terus meningkat setiap tahunnya Selama tahun 2012 terdata adanya peningkatan jumlah kunjungan wisnus yaitu mecapai 7.080.584 orang. Tahun 2013 Dinas Kebudayaan dan Pariwisata (Disbudpar) Kota Bandung optimis menargetkan kunjungan wisatawan dapat menembus jumlah 8 juta orang.
Sejalan dengan meningkatnya jumlah kunjungan wisatawan ke Kota Bandung berbanding lurus dengan meningkat dan berkembangnya usaha-usaha pariwisata. Menurut Undang-Undang Republik Indonesia Nomor 10 Tahun 2009 tentang Kepariwisataan terdapat 13 jenis usaha pariwisata dan salah satunya yaitu usaha jasa perjalanan wisata.

Usaha-usaha jasa perjalanan wisata ini kemudian di kenal dengan sebutan Biro Perjalanan Wisata (BPW). BPW merupakan badan usaha yang bersifat komersil yang bertujuan untuk mengatur, menyediakan dan menyelenggarakan pelayanan bagi seseorang atau sekelompok orang yang melakukan perjalanan dengan tujuan utamanya yaitu untuk berwisata. 
TABEL 1.1

PERTUMBUHAN JUMLAH USAHA PERJALANAN WISATA DI KOTA BANDUNG TAHUN 2009 - 2012

\begin{tabular}{|c|c|c|c|c|}
\hline Tahun & Jumlah BPW & Jumlah CBPW & Jumlah APW & Total \\
\hline 2009 & 138 & 18 & 20 & 176 \\
\hline 2010 & 173 & 24 & 25 & 222 \\
\hline 2011 & 242 & 25 & 38 & 305 \\
\hline 2012 (Jun) & 255 & 28 & 50 & 333 \\
\hline
\end{tabular}

Sumber : Dinas Kebudayaan dan Pariwisata Kota Bandung, 2013

Tabel 1.1 menunjukkan dari tahun ke tahun jumlah usaha perjalanan wisata semakin bertambah. Salah satu perusahaan Biro Perjalanan Wisata (BPW) yang menjadi anggota ASITA (Association of the Indonesia Tours and Travel) dan yang sedang mengembangkan usahanya serta memiliki kemampuan unggul ialah Marga Tour Bandung.

Marga Tour adalah biro perjalanan wisata yang berdiri sejak tahun 2005 dan beralamat di Jalan Sederhana No.34 Sukajadi Bandung. Marga Tour berkomitmen untuk memberikan pelayanan prima kepada pelanggannya. Di bawah pimpinan Bapak Muhammad Haris Zulkarnain, Marga Tour berusaha untuk terus memperbaiki kualitas dalam pelayanan serta meningkatkan komunikasi dengan pelanggan dalam menyediakan jasa paket wisata (tour package).

Selaras dengan slogan perusahaan "Everyday is Holiday", produk utama Marga Tour yaitu menyediakan jasa paket perjalanan wisata. Adapun data mengenai tingkat penjualan jasa paket wisata dari tahun 2009 hingga 2014, seperti yang ditunjukkan pada Tabel 1.4 sebagai berikut:

TABEL 1.2

TINGKAT PENJUALAN PAKET WISATA MARGA TOUR

TAHUN 2009-2014

\begin{tabular}{|c|c|c|c|}
\hline No. & Tahun & Total Paket Wisata & Total Peserta Paket Wisata \\
\hline 1. & 2009 & 35 unit & 2.079 orang \\
\hline 2. & 2010 & 97 unit & 6.986 orang \\
\hline 3. & 2011 & 91 unit & 7.156 orang \\
\hline 4. & 2012 & 72 unit & 5.481 orang \\
\hline 5. & 2013 & 43 unit & 4.227 orang \\
\hline 6. & 2014* (Januari -Maret) & 6 unit & 545 orang \\
\hline
\end{tabular}

Sumber : Modifikasi Data Marga Tour, 2014

Tabel 1.2 menunjukkan bahwa tingkat penjualan paket wisata Marga Tour mengalami fluktuasi. Pada tahun 2009 hanya terjual 35 paket tour dengan jumlah peserta tour sebanyak 2.079 orang dan meningkat pada tahun 2010 terjual 97 paket tour dengan jumlah peserta tour sebanyak 6.986 orang. Pada tahun 2011, jumlah paket tour mengalami penurunan, tetapi jumlah peserta tour naik menjadi 7.156 orang. Pada tahun selanjutnya jumlah penjualan Marga Tour mengalami penurunan dari jumlah paket tour maupun jumlah peserta tour. Hal ini masih berlangsung hingga tahun 2014 (JanuariMaret).

Menurut wawancara peneliti dengan beberapa staff Marga Tour, adanya penurunan tingkat penjualan disebabkan karena semakin banyaknya perusahaan sejenis (competitor). Serta disebabkan oleh keinginan dan kebutuhan konsumen yang dinamis. Akan tetapi, perusahaan kurang dapat memahami keinginan dan kebutuhan konsumen tersebut. Hal ini membuat meningkatnya keinginan konsumen untuk berganti produk ke perusahaan pesaing lain.

Beberapa hal tersebut merupakan perilaku konsumen yang telah menggunakan jasa Marga Tour. Sesuai dengan Zeithaml dalam Ratnasari, Ririn Tri (2011:120), ada lima langkah yang menyangkut perilaku pasca pembelian (post purchase behavior), yaitu kesetiaan pada perusahaan (loyalty), keinginan berganti produk (switch), keinginan untuk membayar lebih (pay more), respon ke eksternal (External 
Response) dan respon ke perusahaan (Internal Response).

Berdasarkan hal tersebut, pada tanggal 26 Oktober 2013 sampai dengan 29 Oktober 2013 peneliti melakukan pra penelitian untuk mengetahui post purchase behavior dengan menyebarkan kuesioner kepada 20 penggunan jasa paket wisata Marga Tour. Dalam pra penelitian ini, peneliti menggunakan skala pengukuran Likert. Skala Likert digunakan untuk mengukur sikap, pendapat dan persepsi seseorang atau sekelompok orang mengenai fenomena sosial. Penentuan skor tertinggi dan terendah dari indikator-indikator variabel post purchase behavior yang diteliti, yaitu dihitung dengan cara skor tertinggi $5 \times 20=$ 100 sedangkan skor terendah 1 x $20=20$. (Sugiyono, 2010:132)

Adapun hasil dari pra penelitian mengenai post purchase behavior dapat dilihat pada Tabel 1.3 berikut ini.

TABEL 1.3

HASIL PRA PENELITIAN FUTURE INTENTION POST-PURCHASE BEHAVIOR DI MARGA TOUR BANDUNG

\begin{tabular}{|c|c|c|c|c|}
\hline No & Pertanyaan & Skor & $\begin{array}{l}\text { Skor } \\
\text { Ideal }\end{array}$ & Keterangan \\
\hline 1. & $\begin{array}{l}\text { Marga Tour sebagai pilihan } \\
\text { pertama dalam } \\
\text { membeli/menggunakan } \\
\text { jasa perjalanan wisata. }\end{array}$ & 69 & 100 & $\begin{array}{l}\text { Konsumen menempatkan Marga Tour } \\
\text { sebagai pilihan pertama dalam } \\
\text { membeli/menggunakan jasa perjalanan } \\
\text { wisata. }\end{array}$ \\
\hline 2. & $\begin{array}{l}\text { Tidak berkeinginan untuk } \\
\text { membeli/menggunakan } \\
\text { jasa perjalanan wisata dari } \\
\text { perusahaan selain Marga } \\
\text { Tour. }\end{array}$ & 54 & 100 & $\begin{array}{l}\text { Konsumen ragu-ragu untuk tidak } \\
\text { membeli/menggunakan jasa perjalanan } \\
\text { wisata dari perusahan selain Marga } \\
\text { Tour. }\end{array}$ \\
\hline 3. & $\begin{array}{lr}\text { Tetap membeli } & / \\
\text { menggunakan } & \text { jasa } \\
\text { perjalanan wisata } & \text { Marga } \\
\text { Tour, walaupun terjadi } \\
\text { kenaikan harga. }\end{array}$ & 48 & 100 & $\begin{array}{l}\text { Konsumen ragu-ragu untuk tetap } \\
\text { membeli/menggunakan jasa perjalanan } \\
\text { wisata Marga Tour, walaupun terjadi } \\
\text { kenaikan harga. }\end{array}$ \\
\hline 4. & $\begin{array}{l}\text { Merekomendasikan jasa } \\
\text { perjalanan wisata Marga } \\
\text { Tour kepada orang lain. }\end{array}$ & 52 & 100 & $\begin{array}{l}\text { Konsumen cukup merekomendasikan } \\
\text { jasa perjalanan wisata Marga Tour } \\
\text { kepada orang lain. }\end{array}$ \\
\hline 5. & $\begin{array}{l}\text { Tingkat kepuasaan } \\
\text { terhadap pelayanan Marga } \\
\text { Tour. }\end{array}$ & 68 & 100 & $\begin{array}{l}\text { Konsumen merasa puas terhadap } \\
\text { pelayanan Marga Tour. }\end{array}$ \\
\hline
\end{tabular}

Sumber: Hasil Pra Penelitian (2013)

Berdasarkan Tabel 1.3 menjelaskan bahwa rata-rata konsumen menempatkan Marga Tour sebagai pilihan pertama dalam menggunakan jasa perjalanan wisata dan sudah puas terhadap pelayanan Marga Tour. Akan tetapi upaya konsumen untuk merekomendasikan jasa Marga Tour kepada orang lain (word of mouth) dan keinginan untuk membayar lebih (pay more) masih kurang. Adapun kecenderungan masih mudahnya konsumen berkeinginan untuk berganti produk (swicth). Selain itu, nilai skor keseluruhan item tiap pernyataan masih terpaut cukup jauh di bawah skor ideal 100, hal ini berarti tingkat post purchase behavior di Marga Tour Bandung masih sangat rendah.
Dengan adanya beberapa permasalahan Marga Tour tidak tinggal diam. Marga Tour sedang melakukan berbagai program seperti: 1) Pricing strategy yaitu memberikan harga produk yang bervariasi dan terjangkau kepada para konsumen. 2) Memberikan informasi produk secara rutin kepada konsumen dengan pemanfaatan media sosial seperti Web, Twitter, Facebook dan Blackberry Massanger. Hal ini juga bertujuan untuk tetap menjalin hubungan dengan para pelanggan. 3) Berpartisipasi dalam kegiatan exhibition event demi meningkatkan kepekaan dan kepercayaan konsumen terhadap jasa perjalanan yang ditawarkan oleh Marga Tour. 4) Meningkatkan kinerja pelayanan (service performance) staff Marga Tour. Saat adanya 
pertemuan dan pelatihan dengan beberapa pihak penting yang terkait, Marga Tour sering mengikutsertakan karyawannya agar memiliki potensi yang unggul dan berwawasan luas, serta mampu selalu memberikan pelayanan prima.

Dalam menunjang keberlangsungan kegiatan tour, setiap perusahaan biro perjalanan wisata membutuhkan peran seorang pemimpin perjalanan wisata (tour leader). Tour leader merupakan orang yang berada dijajaran terdepan yang mewakili perusahaan dalam memimpin perjalanan dan memenuhi kebutuhan wisatawan selama kegiatan wisata.

Hal ini diperkuat dengan pengertian Tour Leader, yang dikemukakan oleh Drs. Oka Yoeti pada bukunya "Tours and Travel Management" (2006:111). Dijelaskan bahwa Tour Leader adalah istilah bahasa asing yang terdiri dari dua suku kata yaitu:

1. Tour adalah perjalanan keliling yang memakan waktu lebih dari 3 hari yang diselenggarakan oelh suatu Biro Perjalanan Wisata dengan acara peninjauan dibeberapa titik tempat yang menarik.

2. Leader adalah pemimpin

David Bowie dan Jui Chi Chang (2005:303) menjelaskan tour leader sebagaimana dikemukakan bahwa:

Tour leader is a significant determinant psychologically, spiritually and practically in influencing the success of the tour product. The term 'tour leader' is also used to describe the tour manager, tour conductor, tour director or courier. Tour leader is a psychologist, diplomat, flight attendant, entertainer, news reporter, orator and even translator and miracle professional.

Songshan Huang et al. (2010:5) menyatakan bahwa keahlian dan kecakapan seorang tour leader/guide saat berinteraksi dengan para wisatawan atau konsumen yang menggunakan jasa tour disebut sebagai tour leader/guide performance. Tour leader/guide performance berasal dari Service Performance (SERVPERF).

SERVPERF merupakan alternatif pengukuran kualitas jasa yang diciptakan oleh Cronin dan Taylor pada tahun 1994. Pengukuran kualitas jasa ini tidak memasukkan ekspektasi kualitas pada model penelitiannya. Pengukuran kualitas jasa cukup dihitung berdasarkan performance jasa saat ini. Evaluasi kualitas jasa yang diterima ini dipengaruhi oleh adanya evaluasi jasa dimasa lalu dan kepuasan atau ketidakpuasan konsumen yang timbul ditempat jasa saat ini.

Songshan Huang et al. (2010:17) menyatakan bahwa seorang tour leader/guide harus menguasai empat faktor yaitu professional competence, interpersonal skills and organization, empathy dan problem solving.

Tour leader performance yang dilaksanakan oleh Marga Tour bertujuan untuk menciptakan persepsi kualitas jasa yang baik di dalam benak konsumen. Persepsi konsumen terhadap tour leader performance adalah penilaian yang dirasakan dan yang diterima konsumen terhadap keseluruhan interaksi dan kinerja seorang tour leader dalam pelaksanaan kegiatan tour. Hal ini dapat meningkatkan kepercayaan konsumen terhadap integritas perusahaan dan menciptakan kepuasan dan loyalitas konsumen dalam menggunakan jasa Marga Tour. Hal ini diperkuat dengan pernyataan Alford dan Sherrell (1996), bahwa service performance akan menjadi prediktor yang baik bagi kualitas jasa atau pelayanan.

Konsumen dapat menyikapi service performance melalui perilaku pasca pembelian (post purchase behavior). Perilaku setelah pembelian akan menimbulkan sikap puas atau tidak puas pada konsumen, maka kepuasan konsumen merupakan fungsi dari harapan pembeli atas produk atau jasa dengan kinerja yang dirasakan (Spreng, Mackenzie dan Olshvskhy, 1996).

Dengan fenomena yang terjadi pada Marga Tour, penulis perlu untuk melakukan penelitian lebih lanjut mengenai "Kinerja Tour Leader dalam Meningkatkan Perilaku Pasca Pembelian di Masa yang Akan Datang Paket Wisata Di Marga Tour" (Survei terhadap Wisatawan yang Menggunakan Paket Wisata Marga Tour Bandung) atau "Tour Leader Performance on Improving The Tour Packages Future Intention Post-Purchase Behavior in Marga Tour" (Survey of Tourist who Use The Tour Packages in Marga Tour Bandung)

\subsection{Rumusan Masalah}

Berdasarkan uraian pada latar belakang, dapat diidentifikasikan beberapa permasalahan sebagai berikut:

1. Bagaimana gambaran tour leader performance di Marga Tour Bandung. 
2. Bagaimana gambaran post purchase consumer behavior di Marga Tour Bandung.

3. Bagaimana pengaruh tour leader performance terhadap post purchase consumer behavior dalam menggunakan jasa Marga Tour Bandung.

\subsection{Tujuan Penelitian}

Tujuan dari penelitian ini antara lain sebagai berikut:

1. Untuk memperoleh temuan mengenai tour leader performance di Marga Tour Bandung.

2. Untuk memperoleh temuan mengenai post purchase consumer behavior di Marga Tour Bandung.

3. Untuk memperoleh temuan mengenai pengaruh tour leader performance terhadap post purchase consumer behavior di Marga Tour Bandung.

\subsection{Kegunaan Penelitian}

Penelitian ini diharapkan:

1. Secara teoritis hasil penelitian ini akan bermanfaat dalam pengembangan ilmu, khususnya mengenai tour leader performance terhadap post purchase consumer behavior di suatu biro perjalanan wisata.

2. Secara praktis penelitian ini dapat menjadi bahan masukan bagi manajemen Marga Tour Bandung, agar mengetahui pengaruh tour leader performance terhadap post purchase consumer behavior di Marga Tour Bandung.

3. Penelitian ini dapat dijadikan suatu bahan penelaah lebih lanjut tentang tour leader performance di suatu biro perjalanan wisata khususnya Marga Tour Bandung terhadap peningkatan post purchase consumer behavior.

\section{KAJIAN PUSTAKA}

\subsection{Kajian Pustaka}

\subsubsection{Konsep Tour Leader Performance}

Bagian dari Service Performance

Pemasaran Jasa

Pemasaran adalah kegiatan mengatur lembaga dan proses untuk menciptakan, mengkomunikasikan, memberikan dan menukarkan penawaran nilai kepada pelanggan, klien, mitra dan masyarakat. (Asosiasi Pemasaran Amerika dalam Kotler dan Keller, 2012:5)

Jasa (service) menurut Kotler (2009:386) adalah "A service is any act of performance that one part can offer to another that essentially intangible and does not result in the ownership of anything its production may or may not be tied to physical product". Jasa merupakan setiap tindakan atau kinerja yang ditawarkan oleh suatu pihak kepada pihak lainnya yang secara prinsip tidak berwujud atau tidak menyebabkan perpindahan kepemilikan.

Menurut Parasuraman (1985:42) sebagian besar jasa tidak berwujud (Bateson 1977, Berry 1980, Lovelock 1981, Shostak 1977). Kebanyakan jasa tidak dapat dihitung, diukur, diinventarisasi, diuji, dan diverifikasi sebelum dibeli untuk menjamin kualitas. Karena tidak berwujud, perusahaan mungkin akan sulit untuk memahami bagaimana pelanggan merasakan jasa mereka dan mengevaluasi kualitas pelayanan (Zeithaml 1981)

Kinerja jasa bervariasi dari produsen ke produsen, dari pelanggan ke pelanggan, dan dari hari ke hari. Konsistensi perilaku dari petugas jasa (yaitu, kualitas yang sama) sulit untuk dipastikan (Booming dan Bitner, 1981) karena apa yang perusahaan maksudkan dalam memberikan jasa mungkin sama sekali berbeda dari apa yang konsumen terima.

Produksi dan konsumsi berbagai jasa tidak dapat dipisahkan (Carmen dan Langeard 1980, Gronroos 1978, Regan 1963, Upah 1980). Kualitas terjadi selama pelayanan, biasanya dalam interaksi antara pelanggan dan penghubung dari perusahaan jasa (Lehtinen dan Lehtinen 1982). Terkadang masukan konsumen (deskripsi tentang bagaimana potongan rambut akan terlihat, deskripsi dari gejala-gejala) menjadi penting dalam kualitas kinerja pelayanan (service performance).

\subsubsection{Service Performance Bagian dari Consumer Behavior}

Perilaku konsumen menurut AMA dalam Peter and Olson (2010:5) consumer behavior is the dynamic interaction of affect and cognition, behavior, and the environment by which human beings conduct the exchange aspects of their lives.

Schiffman and Kanuk (2010:23) menyatakan bahwa consumer behavior is consumer display in searching for purchasing, using, evaluating, and disposing of products and services that they expect will satisfy their needs.

Berdasarkan pengertian tersebut, consumer behavior mengacu pada pemahaman penyedia jasa mengenai 
keputusan pembelian dan penggunaan jasa. Selanjutnya pemahaman mengenai tindakan selanjutnya yang akan dilakukan pelanggan setelah mengkonsumsi jasa (service consumption) tersebut (Lovelock and Wirtz, 2011:58).

Menurut Lovelock (2011:268), ketika pelanggan menentukan untuk menggunakan suatu jasa, pelanggan melalui tiga tahap proses yang digambarkan dalam Gambar 2.1 pada halaman berikut:

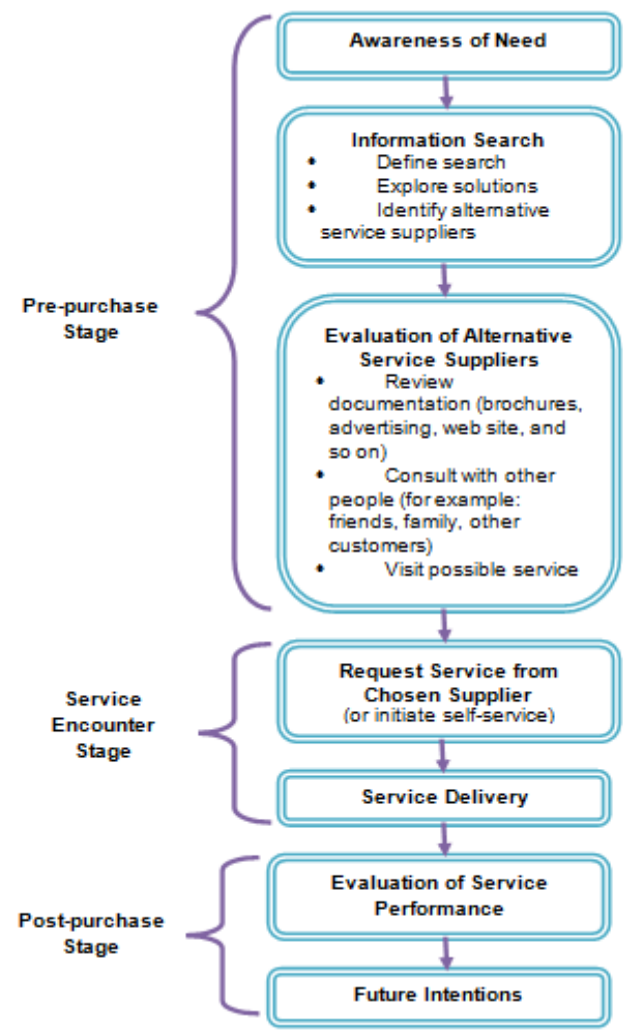

Sumber: Lovelock (2011:268)

GAMBAR 2.1

THE PURCHASE PROCESS:

CUSTOMER ACTIVITIES IN

SELECTING, USING, AND

EVALUATING SERVICE

Berdasarkan Gambar 2.1 dijelaskan bagaimana proses pelanggan dalam melakukan pembelian atau menggunakan suatu jasa, yaitu:

1. Prepurchase stage, merupakan kesadaran pelanggan akan suatu kebutuhan da melalui pencarian informasi dan evaluasi dari alternative untuk menentukan apakah akan membeli atau tidak. Tahap ini terdiri dari awareness of need, information search, dan evaluation of alternatives.
2. Service encounter is a period of time during which a customer interacts directly with a service provider. (Lovelock and Wirtz, 2011:68)

3. Post-purchase stage adalah tahap dimana pelanggan mengevaluasi kinerja layanan (service performance) sesuai dengan apa yang telah mereka terima, lalu menentukan kehendak seperti keinginan membeli lagi dari perusahaan yang sama dan merekomendasikan kepada orang lain (Lovelock and Wirtz, 2011:59).

\subsubsection{Definisi Tour Leader Performance}

Songshan Huang, Cathy H. C. Hsu dan Andrew Chan (2011:5) menyatakan bahwa keahlian dan kecakapan seorang tour leader/guide saat berinteraksi dengan para wisatawan atau konsumen yang menggunakan jasa tour disebut sebagai tour leader/guide performance. Tour leader/guide performance berasal dari Service Performance (SERVPERF).

SERVPERF merupakan alternatif pengukuran kualitas jasa yang diciptakan oleh Cronin dan Taylor pada tahun 1994. Pengukuran kualitas jasa ini tidak memasukkan ekspektasi kualitas pada model penelitiannya. Pengukuran kualitas jasa cukup dihitung berdasarkan performance jasa saat ini. Evaluasi kualitas jasa yang diterima ini dipengaruhi oleh adanya evaluasi jasa dimasa lalu dan kepuasan atau ketidakpuasan konsumen yang timbul ditempat jasa saat ini.

\subsubsection{Dimensi Tour Leader Performance}

Songshan Huang, Cathy H. C. Hsu dan Andrew Chan (2011:19) dalam jurnalnya "Tour Guide Performance and Tourist Satisfaction: a Study of the Package Tours in Shanghai" menyatakan dimensi Tour Guide/Tour Leader Performance, antara lain:

\section{Professional Competence}

Kemampuan seorang Tour Guide/Tour Leader untuk memiliki pengetahuan mengenai daya tarik wisata, budaya, destinasi wisata dan gaya hidup masyarakat lokal. Faktor ini juga menuntut seorang Tour Guide/Tour Leader memiliki selera humor yang baik, memiliki kesadaran yang tinggi akan kebutuhan peserta tour, serta memiliki keterampilan komunikasi yang baik.

2. Interpersonal Skills and Organization Seorang Tour Guide/Tour Leader memiliki kemampuan untuk mengatasi 
komplain dari peserta tour. Memiliki sikap dan penampilan yang sopan. Selain itu Tour Guide/Tour Leader dituntut untuk dapat bekerja sama dengan tim, kemampuan berorganisasi, serta kemampuan dalam mengatur waktu.

3. Empathy

Faktor ini dapat digambarkan sebagai pribadi seorang pemandu wisata yang dapat merawat dan memenuhi kebutuhan psikologis para peserta tour. Selain itu juga harus menunjukan passion atau semangat pada pekerjaan mereka sebagai pemandu wisata.

4. Problem Solving

Faktor terakhir yaitu seorang pemandu wisata dituntut sigap dalam mencari solusi pada setiap masalah dan konflik yang tak jarang muncul dalam pengaturan wisata.

\subsection{Konsep Perilaku Pasca Pembelian (Post-Purchase Behavior)}

Dalam penelitian ini, teori post purchase behavior yang digunakan adalah teori menurut Zeithaml dalam Ririn Tri $\mathrm{R}$ (2011:120), terdapat lima langkah yaitu kesetiaan pada perusahaan (loyalty), keinginan berganti produk (switch), keinginan untuk membayar lebih (pay more), respon ke eksternal (External Response) dan respon ke perusahaan (Internal Response). Adapun pengertian beberapa dimensi dan indikator post purchase behavior, antara lain:

1. Kesetiaan pada perusahaan (Loyalty)

a. Membicarakan hal-hal positif mengenai kualitas jasa Marga Tour kepada orang lain.

b. Merekomendasikan jasa Marga Tour kepada orang lain.

c. Mendorong teman atau relasi bisnis untuk berbisnis dengan Marga Tour.

d. Mempertimbangkan Marga Tour sebagai pilihan pertama dalam membeli/menggunakan jasa perjalanan wisata.

e. Melakukan pembelian ulang di waktu mendatang.

2. Keinginan berganti produk (Switch)

a. Mangalihkan pembelian kepada kompetitor Marga Tour karena harga yang lebih baik.

b. Mangalihkan pembelian kepada kompetitor Marga Tour karena kinerja pelayanan yang lebih baik.

3. Keinginan untuk membayar lebih (Pay More) a. Tetap menggunakan/membeli jasa perjalanan wisata di Marga Tour walaupun terjadi kenaikan harga.

b. Membayar dengan harga lebih tinggi dibandingkan dengan harga yang diberikan kompetitor karena manfaat lain yang diberikan oleh Marga Tour.

4. Respon ke eksternal (External Response)

a. Beralih ke kompetitor jika mengalami masalah dengan pelayanan Marga Tour.

b. Mengeluh kepada konsumen lain jika mengalami masalah dengan pelayanan Marga Tour.

5. Respon ke perusahaan (Internal Response)

a. Mengadukan kepada pegawai Marga Tour jika Tour jika mengalami masalah dengan pelayanan Marga Tour

\subsection{Pengaruh Tour Leader Performance terhadap Post-Purchase Behavior}

Service performance merupakan konsep yang sangat penting dalam berinteraksi dengan konsumen, dikarenakan setiap perusahaan dapat menciptakan keunggulan bersaing melalui penciptaan dan penyampaian personnel differentiation dalam berinteraksi dengan konsumen (Farida Jasfar 2009:63).

Konsumen dapat menyikapi service performance melalui perilaku pasca pembelian (post purchase behavior). Perilaku setelah pembelian akan menimbulkan sikap puas atau tidak puas pada konsumen, maka kepuasan konsumen merupakan fungsi dari harapan pembeli atas produk atau jasa dengan kinerja yang dirasakan (Spreng, Mackenzie dan Olshvskhy, 1996).

Dalam perusahaan penyedia jasa perjalanan wisata, peran seorang pemimpin perjalanan (tour leader) sangat diperlukan. Tour leader merupakan orang terdepan yang mewakili perusahaan dalam berinteraksi dengan konsumen yang membeli atau menggunakan jasa perjalanan wisata. Dalam penelitian ini kinerja dari seorang tour leader disebut tour leader performance.

Menurut David Bowie dan Jui Chi Chang (2005), tour leader merupakan faktor yang krusial dalam mencapai kepuasan konsumen. Tour leader merupakan seseorang yang dapat menjual produk tour selanjutnya. Tour leader performance adalah kunci utama dalam mendiferensiasikan suatu perusahaan perjalanan wisata dengan 
pesaingnya. Tour leader performance dapat mempengaruhi kepuasan, citra perusahaan, loyalitas pelanggan dan komunikasi wordof-mouth. Hal-hal tersebut merupakan bagian dari perilaku konsumen pasca pembelian (post purchase behavior).

Pernyataan para ahli tersebut menyimpulkan bahwa kinerja pelayanan dari seorang tour leader (tour leader performance) berperan terhadap perilaku konsumen pasca membeli atau menggunakan (post purchase behavior) di perusahaan perjalanan wisata.

\subsection{Hipotesis}

Berdasarkan pemaparan teori yang telah dijelaskan bahwa terdapat pengaruh tour leader performance terhadap postpurchase behavior, maka hipotesis dalam penelitian ini adalah:

Terdapat pengaruh yang signifikan antara tour leader performance yang terdiri dari Professional Competence, Interpersonal Skills and Organzation, Empathy, dan Problem Solving terhadap terhadap future intention post-purchase behavior.

\section{METODE PENELITIAN}

\subsection{Objek Penelitian}

Penelitian ini menganalisis bagaimana kinerja pelayanan seorang tour leader (tour leader performance) dan pengaruhnya terhadap perilaku pasca pembelian di masa yang akan datang (future intention postpurchase behavior) di Marga Tour. Variabel independent (bebas) adalah tour leader performance (X) yang memiliki empat dimensi yang terdiri professional competence $\left(\mathrm{X}_{1.1}\right)$, interpersonal skills and organization $\left(\mathrm{X}_{1.2}\right)$, empathy $\left(\mathrm{X}_{1.3}\right)$, dan problem solving $\left(\mathrm{X}_{1.4}\right)$. Variabel dependent (terikat) yaitu perilaku pasca pembelian di masa yang akan datang (future intention post-purchase behavior) yang terdiri dari kesetiaan pada perusahaan (loyalty), keinginan berganti produk (switch), keinginan untuk membayar lebih (pay more), respon ke eksternal (External
Response) dan respon ke perusahaan (Internal Response).

Penelitian ini dilaksanakan di suatu perusahaan dalam industri pariwisata, yaitu PT. Marga Indonesia pada biro perjalanan wisata Marga Tour Bandung. Unit analisis atau responden dalam penelitian ini adalah wisatawan yang telah melakukan pembelian atau menggunankan jasa paket wisata di Marga Tour Bandung.

\subsection{Metode Penelitian}

Berdasarkan variabel=variabel yang diteliti maka metode penelitian yang dipergunakan adalah metode deskriptif dan verifikatif.

\subsection{Metode Penaliran Sampel}

Ukuran sampel yang dihitung dengan menggunakan rumus Slovin. Berdasarkan rumus tersebut, maka jumlah responden yang dijadikan ukuran sampel dalam penelitian ini adalah sebanyak 100 responden.

\subsection{Teknik Pengumpulan Data}

Teknik pengumpulan data yang digunakan oleh penulis adalah Kuesioner, Studi Literatur, Wawancara, dan Observasi.

\subsection{Pengujian Validitas dan Reliabilitas}

Sebelum didistribusikan kepada responden, instrumen penelitian yang berupa kuesioner diuji terlebih dahulu. Uji yang dilakukan meliputi uji validitas dan uji reliabilitas. Hasil menunjukkan bahwa instrumen valid dan reliabel.

\section{HASIL PENELITIAN DAN PEMBAHASAN \\ 4.1 Rekapitulasi Hasil Tanggapan \\ Wisatawan Terhadap Tour Leader Performance di Marga Tour \\ Berdasarkan pada penilaian} keseluruhan variabel dan indikator tour leader performance, maka diperoleh hasil rekapitulasi seluruh tanggapan wisatawan, berikut ini: 
TABEL 4.1

REKAPITULASI HASIL TANGGAPAN WISATAWAN TERHADAP TOUR LEADER PERFORMANCE DI MARGA TOUR

\begin{tabular}{|c|c|c|c|c|}
\hline No & Sub Variabel & Total Skor & Skor Rata-rata & $\%$ \\
\hline 1. & Professional Competence & 2778 & 396,85 & $32,37 \%$ \\
\hline 2. & $\begin{array}{l}\text { Interpersonal Skills and } \\
\text { Organization }\end{array}$ & 2308 & 384,66 & $26,89 \%$ \\
\hline 3. & Empathy & 2752 & 393,14 & $32,07 \%$ \\
\hline 4. & Problem Solving & 743 & 371,5 & $8,66 \%$ \\
\hline & Total & 8581 & 1546,15 & $100 \%$ \\
\hline
\end{tabular}

Sumber : Hasil Pengolahan data 2014

Berdasarkan hasil pengolahan data pada Tabel 4.16, maka dapat dihitung presentase untuk variabel tour leader performance berdasarkan rumus Sugiyono (2012:94) sebagai berikut:

- Nilai Indeks Maksimum = skor tertinggi $\mathrm{x}$ jumlah item $\mathrm{x}$ jumlah responden $=5 \times 22 \mathrm{x}$ $100=11000$

- Nilai Indeks Minimum = skor terendahi $\mathrm{x}$ jumlah item $\mathrm{x}$ jumlah responden $=1 \mathrm{x} 22 \mathrm{x}$ $100=2200$

- Jenjang Variabel = Nilai indeks maksimum - Nilai indeks minimum $=11000-2200=$ 8800

- Jarak Interval = Jenjang : Banyaknya kelas interval $=8800: 5=1760$

\begin{abstract}
- Presentase Interval $=[($ total skor $)$ : nilai maksimum] $\mathrm{x} 100 \%=(8581: 11000) \mathrm{x}$ $100 \%=78.01 \%$
\end{abstract}

Secara ideal skor yang diharapkan untuk jawaban wisatawan yang telah menggunakan paket perjalanan wisata di Marga Tour terhadap pertanyaan 1-22 adalah 11000. Dan perhitungan diperoleh hasil total skor sebesar 8581 atau dengan persentase sebesar $78,01 \%$ dari skor idealnya yaitu 11000. Hasil tersebut menunjukan bahwa tour leader performance di Marga Tour dapat dikatakan tinggi. Hasil ini secara kontinum dapat dibuat kategori sebagai berikut.

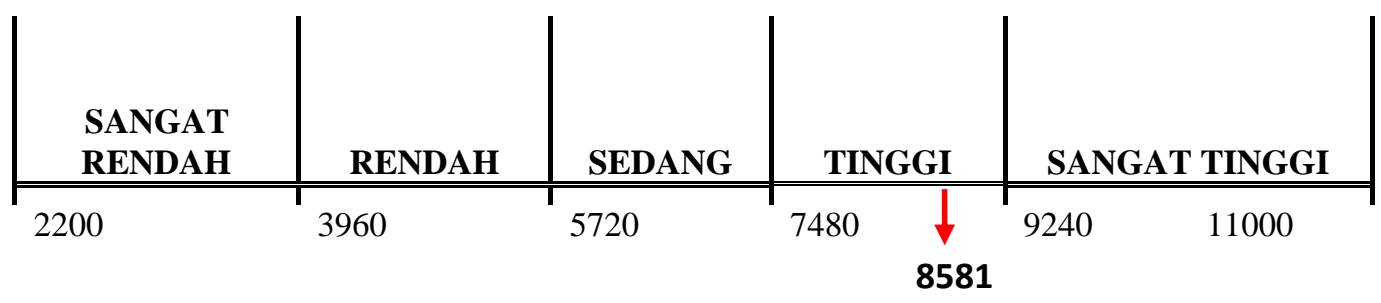

Sumber: Pengolahan Data 2014

GAMBAR 4.1

VARIABEL TOUR LEADER PERFORMANCE PADA GARIS KONTINUM
4.2 Rekapitulasi Hasil Tanggapan
Wisatawan Terhadap Post-Purchase
Behavior
Berdasarkan pada penilaian
purchase behavior, maka diperoleh hasil rekapitulasi seluruh tanggapan wisatawan yang di sajikan pada Tabel 4.2 sebagai berikut: keseluruhan variabel dan indikator post-

TABEL 4.2

REKAPITULASI HASIL TANGGAPAN WISATAWAN TERHADAP POST-PURCHASE BEHAVIOR DI MARGA TOUR

\begin{tabular}{|c|l|c|c|c|}
\hline No & \multicolumn{1}{|c|}{ Sub Variabel } & Total Skor & $\begin{array}{c}\text { Skor } \\
\text { Rata-rata }\end{array}$ & $\%$ \\
\hline 1. & Loyalty & 1876 & 375,2 & $47,36 \%$ \\
\hline 2. & Switch & 620 & 310 & $15,65 \%$ \\
\hline 3. & Pay More & 619 & 309,5 & $15,62 \%$ \\
\hline
\end{tabular}




\begin{tabular}{|c|c|c|c|c|}
\hline 4. & External Response & 608 & 304 & $15,35 \%$ \\
\hline 5. & Internal Response & 238 & 238 & $6,01 \%$ \\
\hline \multicolumn{2}{r|}{ Total } & 3961 & 1536,7 & $100 \%$ \\
\hline
\end{tabular}

Sumber : Hasil Pengolahan data 2014

Berdasarkan hasil pengolahan data pada Tabel 4.2, maka dapat dihitung presentase untuk variabel post-purchase behavior berdasarkan rumus Sugiyono (2012:94) sebagai berikut:

- Nilai Indeks Maksimum = skor tertinggi $\mathrm{x}$ jumlah item $\mathrm{x}$ jumlah responden $=5 \times 12 \mathrm{x}$ $100=6000$

- Nilai Indeks Minimum = skor terendahi x jumlah item $\mathrm{x}$ jumlah responden $=1 \mathrm{x} 12 \mathrm{x}$ $100=1200$

- Jenjang Variabel = Nilai indeks maksimum - Nilai indeks minimum $=6000-1200=$ 4800

- Jarak Interval = Jenjang : Banyaknya kelas interval $=4800: 5=960$
- Presentase Interval $=[($ total skor $):$ nilai maksimum] $\mathrm{x} 100 \%=(3961: 6000) \mathrm{x}$ $100 \%=66,02 \%$

Secara ideal skor yang diharapkan untuk jawaban wisatawan yang telah menggunakan paket perjalanan wisata di Marga Tour terhadap pertanyaan 1-12 adalah 6000. Dan perhitungan diperoleh hasil total skor sebesar 3961 atau dengan persentase sebesar $66,02 \%$ dari skor idealnya yaitu 6000. Hasil tersebut menunjukan bahwa post purchase behavior di Marga Tour dapat dikatakan cukup tinggi. Hasil ini secara kontinum dapat dibuat kategori sebagai berikut.

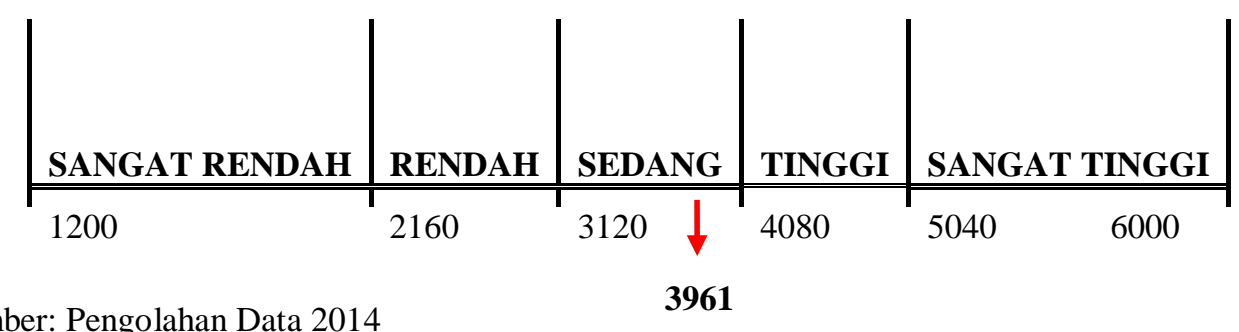

Sumber: Pengolahan Data 2014

VARIABEL POST-PURCHASE BEHAVIOR PADA GARIS KONTINUM 
4.3 Pengaruh Tour Leader Performance

Terhadap Post-Purchase Behavior

Secara lengkap hasil pengolahan data tour leader performance $(\mathrm{X})$ terhadap post- purchase behavior $(\mathrm{Y})$ disajikan secara rinci dalam table berikut ini:

TABEL 4.3

MATRIKS KORELASI ANTAR SUB VARIABEL TOUR LEADER PERFORMANCE DENGAN POST-PURCHASE BEHAVIOR DI MARGA TOUR

\begin{tabular}{|c|c|c|c|c|c|}
\hline & $\begin{array}{c}\text { Post- } \\
\text { Purchase } \\
\text { Behavior (Y) }\end{array}$ & $\begin{array}{l}\text { Professional } \\
\text { Competence } \\
\qquad\left(X_{1.1}\right)\end{array}$ & $\begin{array}{c}\text { Interpersonal } \\
\text { Skills and } \\
\text { Organization } \\
\left(X_{1.2}\right)\end{array}$ & $\begin{array}{c}\text { Empathy } \\
\left(X_{1.3}\right)\end{array}$ & $\begin{array}{c}\text { Problem } \\
\text { Solving } \\
\left(X_{1.4}\right)\end{array}$ \\
\hline $\begin{array}{l}\text { Post-Purchase } \\
\text { Behavior (Y) }\end{array}$ & 1,000 & 0,466 & 0,473 & 0,217 & 0,362 \\
\hline $\begin{array}{c}\text { Professional } \\
\text { Competence } \\
\left(X_{I . I}\right)\end{array}$ & 0,466 & 1,000 & 0,787 & 0,397 & 0,318 \\
\hline $\begin{array}{c}\text { Interpersonal } \\
\text { Skills and } \\
\text { Organization } \\
\left(X_{I .2}\right) \\
\end{array}$ & 0,473 & 0,787 & 1,000 & 0,388 & 0,201 \\
\hline $\begin{array}{c}\text { Empathy } \\
\left(X_{1.3}\right)\end{array}$ & 0,217 & 0,397 & 0,388 & 1,000 & 0,525 \\
\hline $\begin{array}{c}\text { Problem } \\
\text { Solving } \\
\left(X_{1.4}\right)\end{array}$ & 0,362 & 0,318 & 0,201 & 0,525 & 1,000 \\
\hline
\end{tabular}

Sumber : Hasil Pengolahan data 2014

Berdasarkan teori bahwa terdapat pengaruh tour leader performance yang terdiri dari competence $\left(\mathrm{X}_{1.1}\right)$, interpersonal skills and organization $\left(\mathrm{X}_{1.2}\right)$, empathy $\left(\mathrm{X}_{1.3}\right)$, dan problem solving $\left(\mathrm{X}_{1.4}\right)$ terhadap post-purchase behavior $(\mathrm{Y})$ akan dilakukan uji $\mathrm{F}$ untuk mengetahui hasil hipotesis. Secara lengkap hasil pengolahan data uji keseluruhan/simultan (Uji F) melalui program IBM SPSS 20 disajikan secara rinci sebagai berikut:

TABEL 4.4

UJI KESELURUHAN (UJI F)

\begin{tabular}{|c|c|c|c|c|c|c|}
\hline \multicolumn{7}{|c|}{ ANOVA $^{\text {a }}$} \\
\hline \multirow{2}{*}{ Model } & $\begin{array}{c}\text { Sum of } \\
\text { Squares }\end{array}$ & df & $\begin{array}{c}\text { Mean } \\
\text { Square }\end{array}$ & F & Sig. \\
\hline \multirow{2}{*}{1} & Regression & 1263.568 & 4 & 315.892 & 11.131 & $.000^{\mathrm{b}}$ \\
\cline { 2 - 8 } & Residual & 2696.072 & 95 & 28.380 & & \\
\cline { 2 - 8 } & Total & 3959.640 & 99 & & & \\
\hline
\end{tabular}

Sumber : Hasil Pengolahan data 2014

Berdasarkan hasil output SPSS seperti yang terdapat pada Tabel 4.4 diperoleh nilai $\mathrm{F}$ sebesar 11.131 dengan signifikansi sebesar 0,000 lebih kecil dari 0,05. Sehingga dapat disimpulkan $\mathrm{H}_{\mathrm{o}}$ ditolak, artinya proses perhitungan atau pengujian secara individual dapat dilanjutkan. Untuk lebih jelasnya, pengujian koefisien jalur setiap variabel diperlihatkan dalam Tabel 4.5 berikut ini: 
TABEL 4.5

PENGUJIAN KOEFISIEN JALUR

\begin{tabular}{|c|c|c|c|c|c|c|}
\hline \multicolumn{7}{|c|}{ Coefficients $^{\mathrm{a}}$} \\
\hline & \multirow{2}{*}{ Model } & \multicolumn{2}{|c|}{$\begin{array}{l}\text { Unstandardized } \\
\text { Coefficients }\end{array}$} & \multirow{2}{*}{$\begin{array}{l}\text { Standardized } \\
\text { Coefficients } \\
\text { Beta }\end{array}$} & \multirow[t]{2}{*}{$\mathrm{t}$} & \multirow[t]{2}{*}{ Sig. } \\
\hline & & B & Std. Error & & & \\
\hline \multirow[t]{5}{*}{1} & (Constant) & 11.468 & 5.584 & & 2.054 & .043 \\
\hline & Professional Competence & .238 & .231 & .147 & 1.030 & .305 \\
\hline & $\begin{array}{l}\text { Interpersonal Skills and } \\
\text { Organization }\end{array}$ & .737 & .296 & .350 & 2.491 & .014 \\
\hline & Empathy & -.307 & .222 & -.146 & 1.382 & .170 \\
\hline & Problem Solving & 1.802 & .570 & .322 & 3.163 & .002 \\
\hline \multirow[t]{4}{*}{2} & (Constant) & 11.601 & 5.584 & & 2.078 & .040 \\
\hline & $\begin{array}{l}\text { Interpersonal Skills and } \\
\text { Organization }\end{array}$ & .967 & .193 & .459 & 4.999 & .000 \\
\hline & Empathy & -.298 & .222 & -.142 & $1.344^{-}$ & .182 \\
\hline & Problem Solving & 1.928 & .557 & .345 & 3.463 & .001 \\
\hline \multirow[t]{3}{*}{3} & (Constant) & 8.200 & 4.998 & & 1.641 & .104 \\
\hline & $\begin{array}{l}\text { Interpersonal Skills and } \\
\text { Organization }\end{array}$ & .879 & .183 & .418 & 4.810 & .000 \\
\hline & Problem Solving & 1.557 & .486 & 278 & 3.207 & .002 \\
\hline
\end{tabular}

Sumber : Hasil Pengolahan data 2014

Berdasarkan Tabel 4.26, diketahui bahwa terdapat 3 buah model hasil pengujian koefisien jalur. Pada model pertama, diketahui bahwa terdapat 2 sub variabel yang tidak signifikan. Dengan menggunakan program IMB SPSS 20, secara otomatis di lakukannya proses trimming yaitu proses penghitungan kembali tanpa menyertakan sub variabel yang tidak signifikan. Sehingga dapat diketahui dalam model ke-3 terdapat dua sub-variabel yang signifikan yaitu interpersonal skills and organization dengan nilai signifikansi sebesar 0,000 dan problem solving dengan nilai signifikansi sebesar 0,002.

Secara lengkap untuk mengetahui pengaruh masing-masing variabel tour leader performance terhadap post-purchase behavior disajikan pada Gambar 4.3 sebagai berikut:

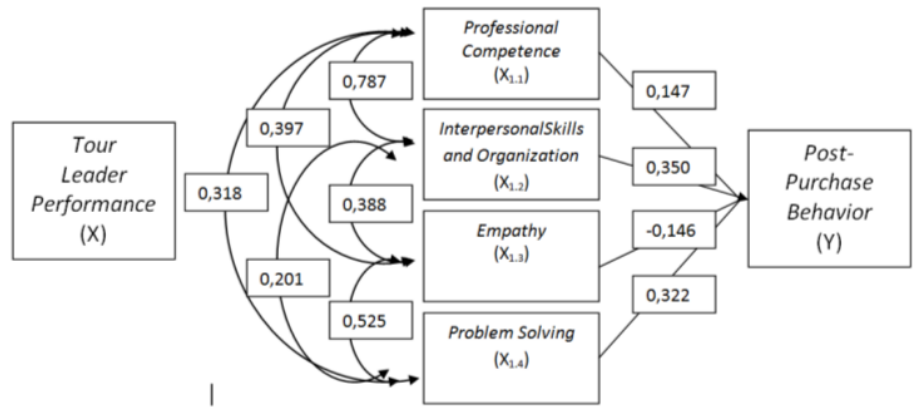

Sumber : Hasil Pengolahan data 2014

GAMBAR 4.3

DIAGRAM JALUR PENGUJIAN SUB HIPOTESIS

Adanya sub variabel yang tidak signifikan maka harus dilakukannya proses trimming. Maka adapun diagram jalur pengujian sub hipotesis yang sudah melalui proses trimming disajikan dalam Gambar 4.4 sebagai berikut: 


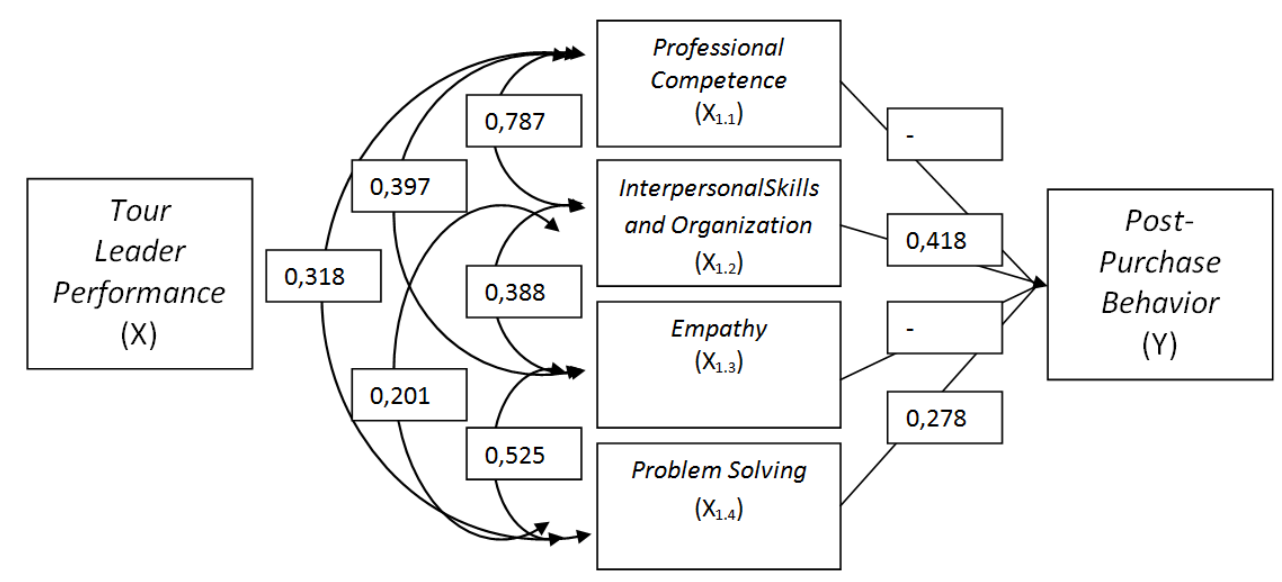

Sumber : Hasil Pengolahan data 2014

GAMBAR 4.4

DIAGRAM JALUR PENGUJIAN SUB HIPOTESIS SETELAH PROSES TRIMMING

Berdasarkan diagram jalur pengujian hipotesis pada Gambar 4.4, maka dilakukan perhitungan untuk mengetahui pengaruh langsung dan tidak langsung antara dimensidimensi yang sesuai dengan Tabel 2.6 sebagai berikut:

TABEL 4.6

HASIL PENGUJIAN KOEFISIEN JALUR, PENGARUH LANGSUNG DAN TIDAK LANGSUNG TOUR LEADER PERFORMANCE TERHADAP POST-PURCHASE BEHAVIOR

\begin{tabular}{|c|c|c|c|c|c|c|}
\hline \multirow[t]{2}{*}{$\mathbf{X}$} & \multirow{2}{*}{$\begin{array}{c}\text { Pengaruh Langsung } \\
\text { Terhadap Y }\end{array}$} & \multicolumn{2}{|c|}{$\begin{array}{c}\text { Pengaruh Tidak Langsung } \\
\text { Melalui }\end{array}$} & \multirow{2}{*}{$\begin{array}{c}\mathbf{R}^{2} \\
\mathbf{Y} \mathbf{X}_{1.2}^{1.2}, \mathrm{X} \\
1.4\end{array}$} & \multirow{2}{*}{ Sig. } & \multirow[t]{2}{*}{ Keputusan } \\
\hline & & $\mathrm{X}_{1.2}$ & $\mathrm{X}_{1.4}$ & & & \\
\hline $\mathrm{X}_{1.2}$ & 0,1747 & - & 0,0233 & 0,198 & 0,000 & $\mathrm{H}_{0}$ ditolak \\
\hline $\mathrm{X}_{1.4}$ & 0,0772 & 0,0233 & - & 0,1005 & 0,002 & $\mathrm{H}_{0}$ ditolak \\
\hline R2 & & & & 0,2985 & & \\
\hline
\end{tabular}

Sumber : Hasil Pengolahan data 2014

Pengujian hipotesis melalui nilai signifikansi menghasilkan penolakan terhadap $\mathrm{H}_{0}$, karena nilai signifikansi lebih keciil dari 0,05 . Hal ini berarti terdapat pengaruh yang signifikan antara tour leader performance yang terdiri dari interpersonal skills and organization dan problem solving terhadap post-purchase behavior di Marga Tour.

Adanya pengaruh antara tour leader performance terhadap post-purchase behavior untuk koefisien jalur lain di luar variabel tersebut ditentukan melalui:

$$
\begin{aligned}
P_{z \varepsilon} & =\sqrt{1-R^{2} Y(X 2, x 4)} \\
& =\sqrt{1-0,2985} \\
& =0.837
\end{aligned}
$$

Hal tersebut berarti interpersonal skills and organization $\left(\mathrm{X}_{1.2}\right)$ dan problem solving $\left(\mathrm{X}_{1.4}\right)$ bersama-sama mempengaruhi post-purchase behavior (Y) sebesar $29,85 \%$ dan sisanya sebesar $(0,837)^{2}=0,700 \times 100 \%$ $=70 \%$ dipengaruhi oleh faktor lain yang tidak masuk dalam penelitian ini.

\section{KESIMPULAN DAN SARAN}

\subsection{Kesimpulan}

Berdasarkan hasil penelitian yang telah dilakukan dengan menggunakan analisis deskriptif dan verifikatif dengan menggunakan path analysis antara tour leader performance dengan post-purchase behavior maka dapat ditarik kesimpulan sebagai berikut :

1. Secara umum gambaran tour leader performance di Marga Tour yang meliputi professional competence, interpersonal skills and organization, empathy dan problem solving telah dilaksanakan cukup baik. Hasil penelitian menunjukan bahwa tour leader performance memiliki pengaruh 
sebesar 29,85\% terhadap post-purchase behavior. Pengaruh tersebut tergolong tidak terlalu besar karena pengaruh lainnya kemungkinan besar ada pada faktor lainnya seperti produk, lokasi dan harga yang tidak diteliti oleh penulis. Adapun penilaian wisatawan paling tingggi adalah professional competence sebagai kemampuan tour leader yang profesional dalam memberikan pelayanan. Sedangkan sub variabel problem solving sebagai keahlian tour leader dalam menghadapi dan menyelesaikan masalah saat kegiatan perjalanan wisata, memiliki penilaian paling rendah dari wisatawan yang menggunakan jasa perjalanan wisata di Marga Tour terhadap tour leader performance.

2. Secara umum gambaran post-purchase behavior di Marga Tour Bandung sudah cukup tinggi. Penilaian terhadap postpurchase behavior dinilai dari beberapa indikator yaitu kesetiaan pada perusahaan (loyalty), keinginan berganti produk (switch), keinginan untuk membayar lebih (pay more), respon ke eksternal (External Response) dan respon ke perusahaan (Internal Response). Jawaban responden menunjukan bahwa hasil indikator dengan nilai tertinggi dan memiliki pengaruh besar terhadap post-

TABEL 5.1

OPERASIONALISASI DAN RENCANA TINDAKAN DI MARGA TOUR

\begin{tabular}{|c|c|c|c|}
\hline Saran yang Diajukan & $\begin{array}{l}\text { Penanggung } \\
\text { Jawab }\end{array}$ & $\begin{array}{c}\text { Waktu } \\
\text { Pelaksanaan }\end{array}$ & $\begin{array}{c}\text { Sumber Daya } \\
\text { yang Diperlukan }\end{array}$ \\
\hline \multicolumn{4}{|c|}{ Interpersonal Skills and Organization } \\
\hline $\begin{array}{l}\text { Pemberian memotivasi kerja dan } \\
\text { memberikan fasilitas bagi tour leader } \\
\text { dalam rangka memberikan kinerja } \\
\text { yang maksimal dan menghasilkan } \\
\text { pelayanan yang berkualitas. }\end{array}$ & Manajer HRD & 2 hari & $\begin{array}{l}\text { - Motivator } \\
\text { - Program } \\
\text { internal } \\
\text { perusahaan }\end{array}$ \\
\hline $\begin{array}{l}\text { Memberikan kesempatan pada } \\
\text { karyawan khususnya tour leader } \\
\text { untuk mendapatkan pelatihan dan } \\
\text { pembekalan yang bertujuan } \\
\text { menambah wawasan dan } \\
\text { meningkatkan skill para tour leader. }\end{array}$ & Manajer HRD & 2 hari & $\begin{array}{l}\text { - Seminar atau } \\
\text { training } \\
\text { mengenai } \\
\text { kepariwisataa } \\
\mathrm{n}\end{array}$ \\
\hline \multicolumn{4}{|c|}{ Problem Solving } \\
\hline $\begin{array}{l}\text { Memberikan kesempatan pada } \\
\text { karyawan khususnya tour leader } \\
\text { untuk mendapatkan pembekalan yang } \\
\text { bertujuan menambah wawasan dan } \\
\text { meningkatkan skill para tour leader } \\
\text { dalam menghapi dan menyelesaikan } \\
\text { masalah yang sering muncul dalam } \\
\text { kegiatan perjalanan wisata. }\end{array}$ & Manajer HRD & 1 hari & $\begin{array}{l}\text { - Seminar atau } \\
\text { training } \\
\text { mengenai } \\
\text { kepariwisataa } \\
\mathrm{n}\end{array}$ \\
\hline
\end{tabular}

purchase behavior yaitu loyalty. Hal ini menunjukan bahwa penilaian positif wisatawan atas pengalamannya menggunakan paket perjalanan wisata di Marga Tour membuat wisatawan ingin kembali melakukan pembelian pada Marga Tour dan bersedia membicarakan serta merekomendasikan hal-hal positif Marga Tour kepada orang lain.

3. Berdasarkan pengujian hipotesis dengan teknik analisis jalur menunjukan terdapat pengaruh yang signifikan antara tour leader performance terhadap postpurchase behavior. Besarnya pengaruh antara variabel $\mathrm{X}$ yaitu tour leader performance terhadap variabel $\mathrm{Y}$ yaitu post-purchase behavior sebesar 29,85\%. Sedangkan sisanya dipengaruhi oleh faktor lain yang tidak diteliti dalam penelitian ini.

\subsection{Saran}

Hasil penelitian menunjukkan bahwa adanya pengaruh yang signifikan antara tour leader performance yang terdiri dari interpersonal skills and organization dan problem solving terhadap post-purchase behavior. Maka adapun operasionalisasi dan rencana tindakan yang direkomendasikan penulis untuk perusahaan Marga Tour antara lain sebagai berikut: 
Sumber: Pengolahan Data 2014

Tabel $\quad 5.1 \quad$ menunjukkan operasionalisasi dan rencana tindakan yang direkomendasikan penulis untuk perusahaan Marga Tour. Dengan dilaksanakannya saransaran yang telah disebutkan dapat meningkatkan kinerja dan kemampuan tour leader dalam memberikan pelayanan sehinggal dapat berpengaruh pada peningkatan post-purchase behavior di Marga Tour.

\section{DAFTAR PUSTAKA}

Ali Hasan. 2009. Edisi Baru Marketing. Yogyakarta : Media Pressindo.

Buchori Alma. 2008. Manajemen Pemasaran dan Pemasaran Jasa. Bandung: Alfabeta.

David Bowie and Jui Chi Chang. 2005. Tourist Satisfaction: A view from a mixed international guided package tour. Journal homepage : www. sagepublication.com

Griffin, R. W. dan Ronald J. Elbert. 2006. Business $8^{\text {th }}$ Edition. New Jersey : Pretince Hall

Huriyati Ratih. 2010. Bauran Pemasaran dan Loyalitas Konsumen. Bandung : Alfabeta.

I Gede Pitana dan Putu G. Gayatri. 2005. Sosiologi dan Antropologi Pariwisata. Yogyakarta : Andi.

Kotler, Philip, Kevin Lane Keller. 2009. Marketing Management $12^{\text {th }}$ Edition. New Jersey : Prentince Hall.

Kotler, Philip, Kevin Lane Keller. 2012. Marketing Management $14^{\text {th }}$ Edition. New Jersey : Prentince Hall.

Kotler, Philip, John T. Bowen, James C. Makens. 2006. Marketing for Hospitality and Tourism $4^{\text {th }}$ Edition. New Jersey : Prentince Hall.

Kotler, Philip, and Garry Amstrrong. 2009. Principles of Marketing $12^{\text {th }}$ Edition. New Jersey : Prentince Hall.

2012. Principles of Marketing $14^{\text {th }}$ Edition. New Jersey : Prentince Hall.

Lili Adi Wibowo. 2011. Handout Metodologi Penelitian.

Lovelock, Christoper, Jochen Wirtz. 2011. Service Marketing $7^{\text {th }}$ Edition. New Jersey : Pearson Prentice Hall.

Middelton V.T.C. and Clarke J. 2001. Marketing in Travel and Tourism. Butterworth-Heineman : Oxford.
M Kesrul. 2004. Panduan Praktis Pramuwisata Profesional. Yogyakarta: Graha Ilmu.

Morrison, Allastair M. 2002. Hospitality and Travel Marketing $3^{\text {rd }}$ Edition. Delmar : New York. 2010. Hospitality and Travel Marketing $4^{\text {th }} \quad$ Edition. Delmar : New York.

Peter J.P. dan Olson J.C. Consumer Behaviour. Erlangga : Jakarta.

Ririn Tri Ratnasari, S.E., M.Si. dan Mastuti H. Aksa, S.IP. 2011. Teori dan Kasus Manajemen Pemasaran Jasa. Ghalia Indonesia : Bogor

Songshan Huang, Cathy H. C. Hsu and Andrew Chan. 2012. Tour Guide Performance and Tourist Satisfaction: a Study of the Package Tours in Shanghai. Journal homepage www. sagepublication.com/content/34 /1/

Sugiyono, 2010. Metode Penelitian Kuantitatif Kualitatif dan $R \& D$. Alfabeta : Bandung.

, 2011. Metode Penelitian Kuantitatif Kualitatif dan $R \& D$. Alfabeta : Bandung. , 2012. Metode Penelitian Kuantitatif Kualitatif dan $R \& D$. Alfabeta : Bandung.

Sulastri, Cici. 2010. Pengaruh Kinerja Paket Wisata Umrah dan Haji Khusus Terhadap Retensi Pelanggan PT. Amanah Mulia Wisata (AMWA Tours) Sebagai Travel Penyelenggra Umrahdan Haji Khusus di Kota Bandung. UPI : Bandung

This Week Wales. Marketing in Tourism and Travel. 26th Ocktober 1998.

Tjiptono, Fandy. 2012. Pemasaran Jasa. Bayumedia Publishing : Jawa Timur.

Uma Sekaran. 2006. Research Method of Business. Salemba Empat. Jakarta.

Umar Husein. 2003. Metode Riset. Jakarta : PT. Gramedia Pustaka Utama.

Undang-Undang No. 10 Tahun 2009 Tentang Kepariwisataan.

Ulber, Silalahi. 2009. Metode Penelitian Sosial. Bandung : PT. Refika Aditama.

Walker R, John. 2004. Introduction to Hospitality Management. Pearson Education : New Jersey. 
Weaver, Dave \& Laura Lawton. 2006. Tourism Management $3^{\text {rd }}$ Edition. John Wiley \& Sons Australia Ltd : Singapore.

Wibowo. 2007. Manajemen Kinerja. PT. Rajagrafindo Persana : Jakarta.

Yoeti, Oka A. 2006. Tours and Travel Management. PT. Pradnya Paramita : Jakarta

Yohanes Sugiharto. 2007. Pengaruh Kepuasan terhadap Loyalitas Pelanggan. Semarang: VISI edisi XVIII/2007

\section{Sumber Observasi dan Wawancara:}

Excecutive Manager Marga Tour. 2012 dan 2013. Kinerja Perusahaan dan Pemasaran Marga Tour. Bandung.

\section{Website:}

Marga Tour Official Website. 2014. Paket Wisata Marga Tour. (accssesed 2-0314/20.15)[Available http://margatour.com/ ] Kementrian Pariwisata dan Ekonomi Kreatif. 2012. (accssesed 4-1013/9.55) [Available at http://www.budpar.go.id ]

United Nations for World Tourism Organization (UNWTO). 2012. Perkembangan Pariwisata Indonesia (accssesed 20-1-14/08.44) [Available at

http://www.investor.co.id/tourism/un wto-optimis-single-destination-aseanpicu-pariwisata/27916] 